\title{
International Experience, Growth Aspirations, and the Internationalisation of New Ventures
}

\begin{abstract}
The aim of this paper is to investigate the impact of the breadth and depth of international experience on subsequent new venture internationalisation and to what extent growth aspirations affect these relationships. Drawing upon previous literature on international new ventures, human capital and growth aspirations, we tested our hypotheses using longitudinal data from the Comprehensive Australian Study of Entrepreneurial Emergence (CAUSEE). Our results support the hypothesis that breadth of international experience has a positive impact on internationalisation. Depth of international experience on its own does not predict subsequent internationalisation activities. However, results support our hypothesis that the interplay of a high growth aspiration and depth of international experience has a positive effect on internationalisation activities. Our study contributes to the research stream on new venture internationalisation by distinguishing between breadth and depth of international experience, demonstrating that these dimensions are differentially linked to internationalisation. Further, we test for interaction effects between international experience and growth aspirations. We thereby add to the knowledge by illustrating that some types of human capital are only utilised when accompanied by growth aspirations.
\end{abstract}

\section{ZUSAMMENFASSUNG}

Das Ziel dieser Studie ist es, den Einfluss von langandauernden und vielfältigen Auslandserfahrungen auf Internationalisierungsaktivitäten $\mathrm{zu}$ erkunden und in welchem Ausmaß Wachstumsambitionen diese Beziehungen beeinflussen. Wir stützen unsere Hypothesen auf vorherige Literatur über International New Ventures, Humankapital und Wachstumsambitionen und testen diese mit Hilfe von Langzeitdaten aus der Comprehensive Australian Study of Entrepreneurial Emergence (CAUSEE). Die Ergebnisse der Analyse deuten darauf hin, dass eine Vielfalt von Auslandserfahrungen unter den Gründern von jungen Unternehmen einen positive Effekt auf Internationalisierungsaktivitäten ausübt. Langandauernde Auslandserfahrungen für sich allein prognostizieren hingegen keine anschließenden Internationalisierungsaktivitäten. Allerdings zeigen die Ergebnisse der statistischen Analyse, dass ein positiver Interaktionseffekt zwischen der Vielfalt der 
internationalen Erfahrungen und Wachstumsambitionen vorliegt. Unsere Studie trägt zur Erforschung der Internationalisierung von jungen Unternehmen bei, indem wir Langzeitinteraktionseffekte zwischen Auslanderfahrung und Wachstumsambitionen untersuchen und indem wir zwischen verschiedenen Dimensionen von Auslandserfahrung und deren Einfluss auf anschließende Internationalisierungsaktivitäten differenzieren.

\section{SUMMARY HIGHLIGHT}

Contributions: This study contributes to the literature on International New Ventures (INVs). By examining the impact of the multifaceted construct of international experience and growth aspirations as well as their interplay on new venture internationalisation, this study adds to the understanding of what drives internationalisation of new ventures. Thereby, this study extends knowledge from previous studies that investigated different determinants separately.

Purpose/Research Questions: This study investigates human capital and motivational determinants of new venture internationalisation and thereby seeks to answer the following research questions: To what extent does founders' international experience explain subsequent internationalisation activities? To what extent do growth aspirations impact on the relationship between international experience and subsequent internationalisation activities of new ventures?

Results/Findings: Negative binominal regression models are developed and tested on a large sample of nascent and young firms. Results show that while the breadth of international experience is positively related to internationalisation activities, no significant direct relationship could be found for the depth of international experiences. However, there is a significant positive interaction between the depth of international experience and growth aspirations in predicting internationalisation activities. An alternative analysis with international sales as an outcome variable supports the robustness and consistency of the main analysis. Our results show that determinants of internationalisation activities are prevalent at very early stages of firm development and our longitudinal analysis allows examining relationship patterns over a longer time frame.

Theoretical Implications: First, this study suggests that the construct of international experience is not unidimensional. The conceptualisation should differentiate between the breadth and depth of international experience. Second, this study contributes to the research stream on 
international new ventures by testing for interaction effects between international experience and growth aspirations.

Practical Implications: This study demonstrates that a breadth of international experience among founders of new ventures promotes internationalisation activities; whereas long-lasting experiences from a limited number of foreign countries are of a lesser direct value for this purpose.

\section{KEYWORDS}

International New Ventures · Human Capital · Growth Aspirations · Internationalisation Activities

\section{ACKNOWLEDGEMENTS}

The authors would like to thank the editor Hamid Etemad and three anonymous reviewers for their constructive and helpful suggestions and comments during the review process that were of great value for improving the manuscript. We also gratefully acknowledge the significant financial support for the CAUSEE study that made this research possible. The CAUSEE data collection, documentation, and release were funded by The Australian Research Council (grants DP0666616 and LP0776845); the QUT Business School; industry partners BDO Australia and National Australia Bank, and the Australian Government Department of Industry, Innovation and Science.

\section{INTRODUCTION}

For more than two decades, particular interest has grown in the emerging field of international entrepreneurship, reflecting the fusion between entrepreneurship and international business research (McDougall and Oviatt 2000). Interesting questions have emerged as to why some new ventures go international early, while others do not follow an early internationalisation path. Previous research has shown that the capabilities of entrepreneurs may foster an early entry into foreign markets (Acedo and Jones 2007; McDougall et al. 1994). Entrepreneurs use their human capital to gain advantages for business development (Becker 1993; Davidsson and Honig 2003). In the context of internationalisation, international experience builds relevant human capital among new venture teams (McDougall et al. 2003; Reuber and Fischer 1997; 
Westhead et al. 2001). However, it remains largely unclear whether the two dimensions depth and breadth of international experience have differential impact on the internationalisation of new ventures. In addition, entrepreneurial motivations may be critical for internationalisation activities of a new venture (Santos and García 2011; Shane et al. 2003). The utilisation of human capital is not an automatic process but requires motivational catalysts (cf. McMullen and Shepherd 2006). In particular, growth aspirations are a motivational influence that interacts with human capital (Wiklund and Shepherd 2003). Little is known yet as to whether growth aspirations play a moderating role for new venture internationalisation; specifically whether these aspirations have equal or varying interactions with the two dimensions depth and breadth of international experience. Consequently, the investigation of the interplay of these potential determinants may result in interesting findings, such as the influence of entrepreneurial motivations on the utilisation of human capital (Shane et al. 2003).

This study seeks to add to the knowledge about the determinants of new venture internationalisation by investigating the impact of international experience on subsequent internationalisation activities and as to how growth aspirations influence these relationships. We thereby aim to answer the following two research questions: To what extent does founders' international experience explain subsequent internationalisation activities? To what extent do growth aspirations impact on the relationship between international experience and subsequent internationalisation activities of new ventures? In particular, we distinguish between the depth (time spent in a foreign country) and the breadth (number of visited foreign countries) of international experience. Thereby, we establish an important theoretical and empirical differentiation between two dimensions of international experience. Furthermore, we conceptualise internationalisation activities as a multifaceted construct capturing different aspects of cross-border activities rather than relying on a single measure such as exporting, and thereby address the broader theoretical notion as proposed in the international new venture framework (cf. Oviatt and McDougall 1994).

Our theoretical contribution is to extend the current knowledge in the international entrepreneurship literature relating to the impact of human capital and growth aspirations on new venture internationalisation. More specifically, we extend previous studies by theoretically and empirically treating international experience as a two-dimensional construct and demonstrating that the two dimensions breadth and depth of international experience are differently related to subsequent internationalisation activities. We thereby present a nuanced view on the impact of human capital. Secondly, we add to the knowledge stream on new venture 
internationalisation by testing for interaction effects between international experience and growth aspirations and by illustrating that growth aspirations can act as a catalyst for utilising human capital.

This paper is structured as follows: First, we discuss previous research on new venture internationalisation, relevant human capital and growth aspirations which leads to the development of hypotheses and research model. Second, we explain our research methodology and variables drawn from a longitudinal data set. Third, we present results of our negative binominal and logistic regression models. Finally, we discuss the findings from the analysis and state implications.

\section{LITERATURE REVIEW AND HYPOTHESES}

\section{International new ventures (INV) framework}

Traditionally, international business scholars used a stage-based view for examining the internationalisation process (Johanson and Vahlne 1977); e.g. the Uppsala model. This model proposes that firms in the first instance accumulate experience in their domestic market and then gradually enter foreign markets; the internationalisation process begins with culturally and geographically close countries and progressively expands to more distant markets (Johanson and Vahlne 1977). Additionally, the model states that firms start with less binding entry modes such as exporting and move on to stronger commitments such as subsidiaries (Johanson and Vahlne 1977). However, a different type of venture has been found not to follow this stagebased path (McDougall 1989). Consequentially, stage-based frameworks proved not be sufficient for describing these ventures (McDougall et al. 1994). Rather, Oviatt and McDougall (1994) theorised the International New Ventures (INV) framework: An INV is "a business organization that, from inception, seeks to derive significant competitive advantage from the use of resources and the sale of outputs in multiple countries" (Oviatt and McDougall 1994, p. 49).

Different to the stage-based view, internationalisation activities conducted by international new ventures comprise different modes and forms which are not necessarily sequential. The international new venture framework theorizes the incorporation of traditional exporting but also international licensing activities, importing resources and the transfer of knowledge (Oviatt and McDougall 1994). This calls into question the widespread habit of conceptually equating 
"internationalisation" with "exporting" and measuring it accordingly. Arguably, the broader conceptualisation should be reflected in the empirical assessment of internationalisation.

\section{Entrepreneurs' human capital and prior knowledge}

Prior knowledge as a constituent of human capital has been found to be important for the ability to perceive entrepreneurial opportunities (McMullen and Shepherd 2006; Shane and Venkataraman 2000). Shane (2000) argues that the perception of opportunities is influenced by individual differences and that different stocks of information relating to opportunities are the source of entrepreneurship. Entrepreneurs may perceive entering foreign markets as an opportunity for their new venture. Specifically, human capital and the capabilities of the entrepreneur have an impact on internationalisation activities of new ventures (Acedo and Jones 2007; McDougall et al. 1994; Ruzzier et al. 2007). Human capital is embodied in individuals and comprises advantageous skills and knowledge acquired over time (Becker 1993; Davidsson and Honig 2003). Higher levels of relevant human capital are argued to endow entrepreneurs with an advantage in identifying and developing international opportunities (Ruzzier et al. 2007). Formal education is only one constituent of human capital; it also incorporates informal elements such as more broadly accumulated knowledge and experiences (Davidsson and Honig 2003).

According to Oviatt and McDougall (2005) the importance of prior knowledge has been shown in several case studies of INVs. Knowledge from international experience is a key determinant for explaining the internationalisation of new ventures (Clarke et al. 2013; Karra et al. 2008; Zhang et al. 2009). The entrepreneur's knowledge and experiences are likely to trigger and facilitate internationalisation activities (Andersson 2011; Rialp et al. 2005; Santos and García 2011). Consistent with the definition of INVs, which enter foreign markets 'from inception', founders or managers of entrepreneurial firms who have a larger stock of prior international knowledge are more likely to pursue internationalisation activities earlier and to have the skills necessary for operating in different countries (Oviatt and McDougall 2005; Reuber and Fischer 1997). Entrepreneurs with international experience may be better able to overcome barriers to internationalisation (Madsen and Servais 1997). Furthermore, this capability facilitates the accumulation of additional foreign knowledge and thereby decreases the uncertainty associated with operating in foreign markets (Autio et al. 2000). 
Founders' international experience is accumulated due to work, education or personal visits (Oviatt and McDougall 2005; Shane and Venkataraman 2000). Previous literature has conceptualised a firm's international experience as a multifaceted construct (e.g. Clark et al. 2017; Clarke et al. 2013; Takeuchi et al. 2005). We transfer this multidimensionality to the individual and team level and differentiate between two dimensions of international experience - the depth and the breadth of international experience. That is, the amount of time an individual has spent in a country abroad and the number of countries an individual has visited (Leonidou et al. 1998). Both dimensions are likely to differentiate international active firms from domestic ventures (Leonidou et al. 1998) and the multidimensionality expands literature that has assessed the relative or absolute existence or non-existence of international experience among management teams (cf. Carpenter and Fredrickson 2001; Fernhaber et al. 2008).

By spending time abroad - whether for work, education or other reasons - an entrepreneur has been exposed to the foreign culture and learnt about the market characteristics (Leonidou et al. 1998). Thereby, the venture may have a competitive advantage compared to other firms when entering foreign markets. Their founders may be more receptive to international opportunities and due to their human capital be better equipped to exploit them (Oviatt and McDougall 2005; Reuber and Fischer 1997). Previous empirical studies suggest a relationship between the time spent abroad and the extent of international activity (Da Rocha et al. 1990). Additionally, the number of countries visited may foster internationalisation activities of a venture (Leonidou et al. 1998). Having experiences from a breadth of countries may equip entrepreneurs with an international outlook and mindset (Hutchinson et al. 2006). Hutchinson et al. (2006, p.524) found that the experience of living and working in many different markets "created an international mindset within these individuals, which created an awareness of foreign market opportunities from an early stage". We therefore follow a nuanced approach for investigating international experience by differentiating between two dimensions of international experience. This allows to extend a unidimensional examination of this form of human capital. We expect that both dimensions of international experience have a positive effect on internationalisation activities. Accordingly, we state the following hypotheses:

Hypothesis 1a: Greater depth of international experience on the part of founders positively influences the level of internationalisation activities.

Hypothesis 1b: Greater breadth of international experience on the part of founders positively influences the level of internationalisation activities. 


\section{Growth aspiration}

Locke and Latham (2004) state that motivation can affect "how and to what extent they [people] utilize their skills and abilities" (p. 388). Thus, the utilisation of one's knowledge when undertaking an activity may be influenced by motivation (Locke and Latham 2004). In other words, whether and to what extent knowledge and skills are used, can be moderated by motivational influences. Individuals equal in terms of ability and knowledge may perform better than others due to motivational influences (Latham and Locke 1991). Motivation can operate as a moderator of performance (Latham and Locke 1991). Motivation provides the impulse and energy to realise a certain activity (Shane et al. 2003).

Some entrepreneurs are motivated by the aspiration to achieve growth (Hessels et al. 2008). Delmar and Wiklund (2008) define the growth motivation of a small business owner "as the aspiration to expand the business" (p. 438). Growth aspirations of nascent and young firms have frequently been studied in entrepreneurship research; while the terminology has been used interchangeably between growth aspirations, preference or willingness (cf. Douglas 2013; Hermans et al. 2015). In the context of new venture internationalisation, motivations play a critical role for the internationalisation behaviour of a new venture (Acedo and Jones 2007; Santos and García 2011). The aspiration to achieve growth may trigger internationalisation activities (cf. Kyläheiko et al. 2011; Orser et al. 2004) since founders may see internationalisation behaviour as a means to fulfil their growth ambitions and to achieve growth (Davidsson et al. 2010). We adopt the notion that growth aspirations reflect desire for business growth, which may or may not be accompanied by corresponding abilities and means to grow the business; such as relevant human capital (cf. Delmar and Wiklund 2008; Hermans et al. 2015). Hence, entrepreneurs may be intrinsically motivated by the aspiration to achieve business growth. Thereby, and as explained by motivational angles, entrepreneurs may exhibit the willingness or aspirations to grow their business which may then translate into behavioural processes in order to actually achieve growth (Verheul and Van Mil 2011).

These relationships, however, may be more complex and dependent on interactions between entrepreneurs' human capital and their growth aspirations (cf. McMullen and Shepherd 2006; Wiklund and Shepherd 2003). We adopt these theoretical notions to the context of early internationalising ventures and assume that motivations such as growth aspirations affect how human capital in the form of international experience is utilised for potential internationalisation activities. More specifically, we argue for a moderating effect between the human capital variable international experience and the motivational variable growth 
aspirations (cf. Wiklund and Shepherd 2003). Reid (1981) suggests that international experiences cannot be considered as an isolated factor when investigating the entry of foreign markets; rather motivations should be included in this function. This therefore implies interaction effects between the human capital of international experience and the motivation to aspire for growth. Following Zahra et al. (2005), motivations can explain how resources are allocated. Accordingly, the motivation to aspire business growth can affect how the resources of international experiences are allocated.

Building upon this discussion, growth aspirations are likely to influence the relationship between international experience and actual internationalisation activities. We expect a positive impact of growth aspirations on the utilisation for international experience. Accordingly:

Hypothesis 2a: Higher growth aspirations positively moderate the relationship between the depth of international experience and the level of internationalisation activities.

Hypothesis 2b: Higher growth aspirations positively moderate the relationship between the breadth of international experience and the level of internationalisation activities.

Proposed relationships between international experience, growth aspiration and internationalisation activities are shown in Figure 1.

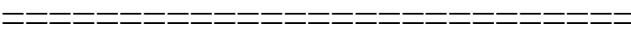

INSERT FIGURE 1 ABOUT HERE

\section{METHODOLOGY}

\section{Research design, data and sample}

This study uses longitudinal data on nascent firms $(n=307)$ and young firms $(n=382)$ from the Comprehensive Australian Study of Entrepreneurial Emergence (CAUSEE) (Davidsson et al. 2011). Entrepreneurs participating in CAUSEE were randomly sampled and interviewed via phone every 12 months for three years (Davidsson et al. 2011). For testing the hypotheses, data from four waves is used. The independent variables are represented by data from wave 1 . The 
dependent variables are represented by the subsequent waves 2, 3 and 4. In other words, the research design traces the level of internationalisation activities over three waves of data collection, allowing testing of each hypothesised relationship with varying time lags. See Davidsson et al. (2011) for a more elaborate description of the CAUSEE sample and data set.

\section{Variables and measures}

Internationalisation activities. The dependent variable in this study is the level of internationalisation activities. Consistent with our broader conceptualisation of internationalisation as including not only exporting but also international licensing activities, importing, and the transfer of knowledge, we developed a formative index capturing this breadth of internationalisation activities (cf. Oviatt and McDougall 1994; Ruzzier et al. 2006; Sullivan 1994). Specifically, the cumulative index comprises whether each of the following five internationalisation activities applies or not: (a) Cross-border collection and/or exchange of information; (b) import of goods or services; (c) international sales of products or services to customers abroad, whether direct or indirect; (d) advanced international sales in the form of direct exports or exports through the firm's own foreign office; and (e) international licensing agreements. Each affirmed activity adds one (1) to the index score. The result is a count variable ranging from 0 to 5 .

International sales is our alternative dependent variable to test for the robustness and consistency of our formative measurement index of internationalisation activities. Respondents were asked whether they sell any products or services to customers in other countries, either directly or indirectly. The variable is dichotomous representing either the presence (coded as 1) or the absence (coded as 0 ) of international sales.

Depth of international experience is operationalised by the total number of years spent in a country other than Australia as an adult after the age of 18 . The number of years of international experience may assist in observing and interpreting potentials to enable internationalisation (Oviatt and McDougall 2005) and has been used in previous studies as an indicator for international experience (Kundu and Katz 2003). The time spent abroad has been found to be an important factor irrespective of whether it was related to education, business, living or tourism (Leonidou et al. 1998). For solo ventures the variable is based on the respondent's international experience whereas for team ventures the respondent was asked to add up the 
number of years abroad across all owners of the venture team. Thus, the depth of international experience is a continuous variable captured at the venture level.

Breadth of international experience is measured as the accumulated number of countries other than Australia in which members of the venture team worked or studied for a period of three months or more as an adult after the age of 18. Previous studies suggest that not only the time spent abroad but also the diversity plays a role for internationalisation activities (Hutchinson et al. 2006; Leonidou et al. 1998). Respondents were asked to add up the total number of countries for all team members if it was not a solo venture. The result is a continuous count variable, reflecting the accumulated number of countries in which venture team members worked or studied abroad.

Growth aspiration is measured by the preference for the future of operating the business to be as large as possible as opposed to operating a smaller manageable business. Respondents representing a venture team were asked to answer on behalf of the entire start-up team. The variable is dichotomous representing either a high growth aspiration (coded as 1) or the absence of growth aspiration (coded as 0 ).

Control variables. The control variables used are stage of development; service vs. goodsproducer; online vs. brick-and-mortar business model; education level; ethnicity, and gender. Stage of development is a dichotomous variable (labelled "Young firm") which is coded ' 0 ' for nascent firms and ' 1 ' for young firms. Nascent firms are defined as active start-ups that when sampled had not yet become operational businesses, while young firms are operational and less than four years old when sampled (Davidsson et al. 2011). Naturally, even if some internationalisation is possible from inception, firms that are fully operational are likely to have more international activities (Sleuwaegen and Onkelinx 2014). In terms of internationalisation activities, there are considerable differences between service- and goods-producing firms (Lewis and Minchev 2001). Therefore, "service" is coded ' 1 ' for firms which predominantly sell services and ' 0 ' for others. Similarly, e-business activities may facilitate internationalisation activities in comparison to pure brick-and-mortar competitors due to wider market access (Davis and Harveston 2000). We therefore include a dichotomous control variable with value ' 1 ' for brick-and-mortar businesses and ' 0 ' for those with any of their sales occurring through online channels. More international experience may correlate with the founders' level of education. Therefore, the analysis accounts for possible effects of higher education in general through a proxy with value ' 1 ' if any team member has a university degree 
and ' 0 ' if otherwise. To account for socio-demographic differences, we control for gender, coded as ' 1 ' if all members of the venture team are male and ' 0 ' if otherwise, and for ethnicity, coded as ' 1 ' if the venture team is of Non-European background and' 0 ' if otherwise.

\section{Data analysis}

Because our internationalisation index is a count variable, we use negative binominal regression for our main analysis. Three moderated regression models are constructed which test hypothesised direct effects and interactions between international experience and growth aspiration on internationalisation activities in waves 2, 3 and 4. By using outcome data from three waves at different points in time we do not aim to compare levels of internationalisation activities; rather we aim to trace the impact of our independent variables over a longer time period in order to assess stability and potential longer-term effects. Our alternative dependent variable, international sales, is dichotomous. We therefore use logistic regression in this case.

\section{RESULTS}

Means, standard deviations and correlations for the observed variables in the model are shown in table 1. Overall, the variables do not show high correlations with each other. Only the outcome variables internationalisation activities drawn from waves 2, 3 and 4 are strongly correlated. However, this was expected since these measure the same construct at different points in time. The remaining variables demonstrate low to moderate correlations (Cohen 1988). This indicates that multicollinearity is not a serious issue in the analyses (Hair et al. 2014). Correlations between independent and dependent variables are in the expected direction.

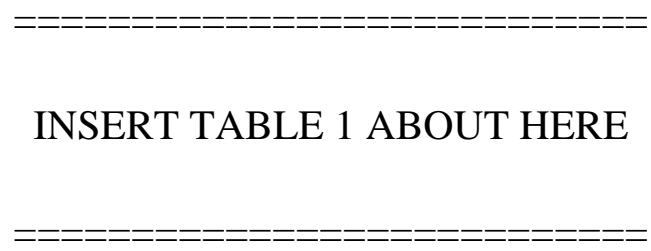

\section{Internationalisation activities}

Results for the negative binominal regression models for hypotheses testing are shown in table 2. The control variables were first entered into a base model for the outcome variables from waves 2, 3 and 4 respectively. In the next step, the independent main effects were entered. Finally, interaction effects were added to the model. 
As hypothesised the breadth of international experience is significantly related to subsequent levels of internationalisation in wave $2(b=.03, p<.01)$ and wave $3(b=.03, p<.05)$. At the time of wave 4 the relationship between the breadth of international experience and internationalisation activities is no longer significant. However, direction and magnitude essentially remain consistent $(b=.02$, n.s.) and the disappearance of significance may be attributed to the attrition in the sample and hence less statistical power (Hair et al. 2014). Contrary to hypothesis 1a there is no significant relationship between the depth of international experience and subsequent internationalisation activities in waves 2, 3 and 4.

The regression coefficients of the interaction terms suggest support for hypothesis $2 \mathrm{a}$, but not for hypothesis $2 \mathrm{~b}$. Growth aspirations moderate the relationship between the depth of international experience and internationalisation activities at the time of wave $2(b=.01, p<$ $.05)$ and wave $3(b=.01, p<.05)$. The effect remains stable in magnitude at wave 4 but is not significant in that analysis $(\mathrm{b}=.01$, n.s.). We again suspect this to be due to the attrition in the sample and consequently less statistical power (Hair et al. 2014). No moderation was found between the breadth of international experience and growth aspirations.

Overall, the small coefficients of the significant relationships indicate a comparatively small magnitude of the effects of the independent variables on the level of internationalisation activities. However, their consistency and their divergence from no effects suggest theoretically and practically important results for the subject matter under investigation. Considering the operationalisation of our dependent variable as a formative index, a judgement in terms of a desirable minimum effect size appears not to be viable (cf. Davidsson 2016). We are confident that results are both theoretically and practically meaningful by, for example, suggesting that an increase in the breadth of international experience is related to higher levels of subsequent internationalisation activities.

In order to further examine the nature of the significant interaction effect between growth aspirations and the depth of international experience, marginal effects analyses were conducted. 
Figure 2 plots the relationship for the outcome variable drawn from wave 2 . The graph confirms that the effects of a high depth of international experience on internationalisation activities are more marked for those new venture teams who have a high growth aspiration.

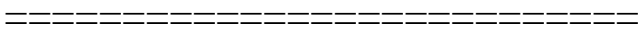

INSERT FIGURE 2 ABOUT HERE

\section{Robustness test: International sales}

Our alternative analysis uses logistic regression testing the same models on the dependent variable international sales. This more conservative outcome variable captures whether or not new ventures sold internationally at the time of waves 2, 3 and 4. For each regression first the control variables were added into a base model, followed by a model for the independent effects and finally a model including interaction effects. Results of the analyses are shown in table 3. Overall, the patterns are consistent with our previous negative binominal regression models with our formative dependent variable. The results again suggest that the breadth (but not depth) of international experiences is significantly associated with subsequent international sales at the time of wave $2(\mathrm{~B}=.16, \mathrm{p}<.05)$, wave $3(\mathrm{~B}=.18, \mathrm{p}<.01)$, and wave $4(\mathrm{~B}=.29, \mathrm{p}<.05)$. The logistic regression analysis also shows a consistently positive interaction effect between growth aspirations and the depth of international experiences on international sales, albeit not significant in wave 3 and only marginally significant in wave 4 (Wave 2 : $\mathrm{B}=.05, \mathrm{p}<.05$; Wave $3: \mathrm{B}=.04$, n.s.; and wave $4: \mathrm{B}=.06, \mathrm{p}<.10)$. The large negative coefficient for the interaction effect of growth aspiration with breadth of international experience at the time of wave 4 is likely spurious in nature as separate tests of the two interaction effects as entered in this model show that neither are significant and both are of lesser magnitude. These interactions may counteract each other and thus can be discounted. Overall, considering attrition and the nature of the dependent variable as indicator of the level of internationalisation we consider this to reflect a satisfactory level of robustness.

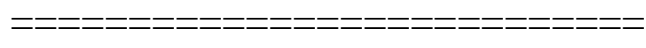

INSERT TABLE 3 ABOUT HERE 


\section{DISCUSSION}

Our study explores the impact of growth aspirations on the relationship between entrepreneurs' international experience and internationalisation activities. Overall, the results follow the pattern of previous studies by suggesting that international experience is beneficial for new venture internationalisation (Oviatt and McDougall 2005; Shane and Venkataraman 2000). However, our extension of previous studies by treating international experience as a twodimensional theoretical construct and by differentiating between the depth and breadth of international experience yields advanced findings. Having a broad international experience that is, having spent time in a variety of foreign countries - appears to be more beneficial for new venture internationalisation than a long-lasting experience from a single country. This plurality relating to many countries may broaden the horizon of the entrepreneur, facilitating the development of a global mindset, rather than a particular strength focussing on, for example, only one foreign country. Our finding is also aligned with Hutchinson et al. (2006) and their discussion that living and working in various countries could develop an international mindset because individuals experience different market environments. Thereby, entrepreneurs are aware of a variety of potential foreign market opportunities. This can also be related to the theoretical and conceptual work on international new ventures, which incorporates a more global rather than gradual and discrete internationalisation (Oviatt and McDougall 1994). The findings emphasise the importance of a founders' breadth of international experience for new ventures who aim to internationalise their firm. It may therefore be more valuable for entrepreneurs to accumulate experiences from a variety of foreign countries. Shorter work stays or study periods abroad appear to be sufficient to equip entrepreneurs with a useful set of tools to foster internationalisation activities.

The analysis revealed a significant interaction effect between growth aspirations and the depth of international experience in predicting internationalisation activities. The breadth of international experience from many countries directly and positively influences levels of internationalisation activities. For a positive influence of the depth of international experience, however, the nature of growth aspirations is crucial. In the absence of an accompanying high growth aspiration, the number of years spent abroad does not significantly impact the level of internationalisation activities. In contrast, having experience from many countries by itself is beneficial for new venture internationalisation; this relationship is not contingent on having high growth aspirations. Whether a venture team is driven by high or low growth orientations 
does not play a pivotal role. Yet growth aspirations do play a role if new venture teams aim to capitalise on a long-lasting experience abroad.

Experiences from a long stay abroad may be seen as given and innate by the members of the venture team and they might not realise benefits from this experience. A high growth aspiration could possibly trigger the perception of international opportunities concealed to others, and foster an engagement in internationalisation activities. Founders highly motivated to achieve a business as large as possible might also be more receptive to realise the internationalisation ideas they ponder (cf. Carsrud and Brännback 2011; Hessels et al. 2008; Shane et al. 2003).

This study revealed only marginal indications for a direct relationship (not hypothesised) between growth aspirations and subsequent internationalisation activities. This suggests consistency with previous research on the relationship between growth motivation and internationalisation (Hessels et al. 2008). One explanation for this could be the variation of motivation across individuals and perceptions of opportunities as outlined by Shane et al. (2003). Accordingly, motivations might matter in some cases, but not in others. For some founders internationalisation may be a means to fulfil their growth aspirations, for others this motivation may result in different means to achieve them, for example growing in the domestic market. Another explanation might be a gap between dream and reality. A new venture may aim to start a business with the motivation to have it become as large as possible. However, new ventures may overestimate their potential and therefore be too optimistic. Yet another explanation is offered by Hennart (2014) proposing that internationalisation activities are linked to the business model of a new venture. Some firms, for example, sell niche products to globally dispersed customers with demand generated of its own volition. This means that new ventures are engaging in internationalisation activities due to the nature of their products and services, without actively seeking to become engaged in foreign markets. Thus, motivation would not play a significant role.

By using a large sample from a longitudinal data set this study is able to observe the impact of international experience and interaction effects with growth aspirations on subsequent internationalisation activities over a longer period of time. Findings suggest that the beneficial impact of human capital on new venture internationalisation and the implementation of growth aspirations is stable and consistent over the time horizon observed. Our study highlights the importance of particular human capital on the internationalisation of new ventures, i.e. the role of depth and breadth of international experience and growth aspirations. Oviatt and McDougall 
(2005) propose that internationalisation activities of international new ventures may be traced back to very early firm stages. This study shows that human capital and growth aspirations as well as the interaction between those partially predict subsequent internationalisation activities in the future. This suggests that growth aspirations and international experience are crucial from the very beginning. These findings support the theoretical framework on international new ventures by demonstrating the relevance of knowledge for new venture internationalisation. Additionally, this study shows that the construct of international experience is not unidimensional. Rather it is suggested to differentiate between the breadth and depth of international experience. These dimensions of human capital have different effects on internationalisation activities among new ventures. Our study thereby presents are more nuanced view on international experience and its impact on subsequent internationalisation activities. This study also contributes to the research stream on new venture internationalisation by testing for the moderating effect of growth aspirations on the utilisation of human capital in the context of internationalisation behaviour. We thereby demonstrate that the implementation of some forms of human capital are contingent on accompanying growth aspirations.

\section{Limitations}

As with every piece of research, this study has its limitations. While this study has the advantage of being able to access longitudinal data, the observed time frame of three years might not be sufficient for all purposes. Future research could investigate new venture internationalisation over a longer time period and test whether similar patterns of the impact of international experience and growth aspirations can be found.

Because we use observational data without experimental control we cannot rule out the possibility that an underlying "international orientation" may have influenced both the breadth and depth of experience among founders and the internationalisation of the venture without the two being causally related. However, we find it unlikely that international experience as such would have no effect on internationalisation activities. On the contrary, we find it likely that our results underestimate the relationships. Although we received relatively solid support for two of our hypotheses ( $1 b$ and $2 a$ ) the coefficients and contributions to explained variance were of modest magnitude. We suspect that this is in part attributable to the nature of some of our measures diluting the true effects. 


\section{CONCLUSION}

The objective of this paper was to investigate the impact of the breadth and depth of international experience on subsequent new venture internationalisation and to what extent growth aspirations affect these relationships. Based on our results we suggest that it is advisable to distinguish between different dimensions of the construct of international experience since these suggest to have varying effects on new venture internationalisation. Our study also emphasizes the important accompanying effect that motivational influences such as growth aspirations have on the internationalisation process. We thereby followed the call to examine interaction effects between motivations and other determinants on entrepreneurial processes. Our study adds to the research stream on international new ventures by distinguishing between the breadth and depth of international experience, illustrating their varying effects on internationalisation activities, and by demonstrating that some human capital is only utilised by accompanying aspirations. 


\section{REFERENCES}

Acedo FJ, Jones MV (2007) Speed of internationalization and entrepreneurial cognition: Insights and a comparison between international new ventures, exporters and domestic firms Journal of World Business 42:236-252 doi:10.1016/j.jwb.2007.04.012

Andersson S (2011) International entrepreneurship, born globals and the theory of effectuation Journal of Small Business and Enterprise Development 18:627-643 doi:10.1108/14626001111155745

Autio E, Sapienza HJ, Almeida JG (2000) Effects of age at entry, knowledge intensity, and imitability on international growth Academy of management journal 43:909-924

Becker G (1993) Human Capital: A theoretical and empirical approach with special references to education Chicago: University of Chicago

Carpenter MA, Fredrickson JW (2001) Top Management Teams, Global Strategic Posture, and the Moderating Role of Uncertainty The Academy of Management Journal 44:533-545 doi:10.2307/3069368

Carsrud A, Brännback M (2011) Entrepreneurial Motivations: What Do We Still Need to Know? Journal of Small Business Management 49:9-26 doi:10.1111/j.1540627X.2010.00312.X

Clark DR, Li D, Shepherd DA (2017) Country familiarity in the initial stage of foreign market selection Journal of International Business Studies:1-31

Clarke JE, Tamaschke R, Liesch PW (2013) International Experience in International Business Research: A Conceptualization and Exploration of Key Themes International Journal of Management Reviews 15:265-279 doi:10.1111/j.1468-2370.2012.00338.x

Cohen J (1988) Statistical power analysis for the behavioural sciences. Hillside NJ: Lawrence Earlbaum Associates

Da Rocha A, Christensen CH, da Cunha CE (1990) Aggressive and passive exporters: a study in the Brazilian furniture industry International Marketing Review 7

Davidsson P (2016) Researching Entrepreneurship. International Studies in Entrepreneurship, vol 33, 2nd edn. Springer International Publishing,

Davidsson P, Achtenhagen L, Naldi L (2010) Small firm growth Foundations and trends in entrepreneurship 6:69-166

Davidsson P, Honig B (2003) The role of social and human capital among nascent entrepreneurs Journal of Business Venturing 18:301-331

Davidsson P, Steffens PR, Gordon SR (2011) Comprehensive Australian Study of Entrepreneurial Emergence (CAUSEE): design, data collection and descriptive results. In. Edward Elgar,

Davis PS, Harveston PD (2000) Internationalization and organizational growth: The impact of Internet usage and technology involvement among entrepreneur-led family businesses Family Business Review 13:107-120

Delmar F, Wiklund J (2008) The Effect of Small Business Managers' Growth Motivation on Firm Growth: A Longitudinal Study Entrepreneurship Theory and Practice 32:437-457 doi:10.1111/j.1540-6520.2008.00235.x

Douglas EJ (2013) Reconstructing entrepreneurial intentions to identify predisposition for growth Journal of Business Venturing 28:633-651 doi:10.1016/j.jbusvent.2012.07.005

Fernhaber SA, Gilbert BA, McDougall PP (2008) International Entrepreneurship and Geographic Location: An Empirical Examination of New Venture Internationalization Journal of International Business Studies 39:267-290

Hair JF, Black WC, Babin BJ, Anderson RE (2014) Multivariate data analysis. vol Book, Whole. Pearson Education Limited, Harlow 
Hennart JF (2014) The Accidental Internationalists: A Theory of Born Globals

Entrepreneurship: Theory and Practice 38:117-135 doi:10.1111/etap.12076

Hermans J, Vanderstraeten J, van Witteloostuijn A, Dejardin M, Ramdani D, Stam E (2015) Ambitious entrepreneurship: A review of growth aspirations, intentions, and expectations. In: Entrepreneurial growth: Individual, firm, and region. Emerald Group Publishing Limited, pp 127-160

Hessels J, Van Gelderen M, Thurik R (2008) Entrepreneurial aspirations, motivations, and their drivers Small Business Economics 31:323-339 doi:10.1007/s11187-008-9134-X

Hutchinson K, Quinn B, Alexander N (2006) The role of management characteristics in the internationalisation of SMEs. Evidence from the UK retail sector Journal of Small Business and Enterprise Development 13:513-534 doi:10.1108/14626000610705723

Johanson J, Vahlne J-E (1977) The internationalization process of the firm--A model of knowledge development and increasing foreign market commitments Journal of International Business Studies (pre-1986) 8:23

Karra N, Phillips N, Tracey P (2008) Building the born global firm: developing entrepreneurial capabilities for international new venture success Long Range Planning 41:440-458

Kundu SK, Katz JA (2003) Born-international SMEs: BI-level impacts of resources and intentions Small Business Economics 20:25-47

Kyläheiko K, Jantunen A, Puumalainen K, Saarenketo S, Tuppura A (2011) Innovation and internationalization as growth strategies: The role of technological capabilities and appropriability International Business Review 20:508-520 doi:10.1016/j.ibusrev.2010.09.004

Latham GP, Locke EA (1991) Self-regulation through goal setting Organizational behavior and human decision processes 50:212-247

Leonidou LC, Katsikeas CS, Piercy NF (1998) Identifying Managerial Influences on Exporting: Past Research and Future Directions Journal of International Marketing 6:74102 doi: $10.2307 / 25048728$

Lewis G, Minchev T (2001) Methodological issues in researching internationalisation strategies of Australian firms. School of Commerce, Flinders University of South Australia,

Locke EA, Latham GP (2004) What Should We Do about Motivation Theory? Six Recommendations for the Twenty-First Century The Academy of Management Review 29:388-403 doi:10.2307/20159050

Madsen TK, Servais P (1997) The internationalization of Born Globals: An evolutionary process? International Business Review 6:561-583 doi:10.1016/S0969-5931(97)00032-2

McDougall PP (1989) International versus domestic entrepreneurship: New venture strategic behavior and industry structure Journal of Business Venturing 4:387-400

McDougall PP, Oviatt BM (2000) International Entrepreneurship: The Intersection of Two Research Paths The Academy of Management Journal 43:902-906 doi:10.2307/1556418

McDougall PP, Oviatt BM, Shrader RC (2003) A comparison of international and domestic new ventures Journal of international entrepreneurship 1:59-82

McDougall PP, Shane S, Oviatt BM (1994) Explaining the formation of international new ventures: The limits of theories from international business research Journal of Business Venturing 9:469-487

McMullen JS, Shepherd DA (2006) Entrepreneurial action and the role of uncertainty in the theory of the entrepreneur Academy of Management Review 31:132-152

Orser B, Riding A, Townsend J (2004) Exporting as a Means of Growth for Women-owned Canadian SMEs Journal of Small Business \& Entrepreneurship 17:153-174 doi:10.1080/08276331.2004.10593317 
Oviatt BM, McDougall PP (1994) Toward a theory of international new ventures Journal of International Business Studies 25:45

Oviatt BM, McDougall PP (2005) Defining international entrepreneurship and modeling the speed of internationalization Entrepreneurship: Theory and Practice 29:537-553 doi:10.1111/j.1540-6520.2005.00097.x

Reid SD (1981) The Decision-Maker and Export Entry and Expansion Journal of International Business Studies 12:101-112 doi:10.2307/154672

Reuber AR, Fischer E (1997) The Influence of the Management Team's International Experience on the Internationalization Behaviors of SMEs Journal of International Business Studies 28:807-825 doi:10.2307/155495

Rialp A, Rialp J, Knight GA (2005) The phenomenon of early internationalizing firms: What do we know after a decade (1993-2003) of scientific inquiry? International Business Review 14:147-166 doi:10.1016/j.ibusrev.2004.04.006

Ruzzier M, Antoncic B, Hisrich RD, Konecnik M (2007) Human Capital and SME Internationalization: A Structural Equation Modeling Study Canadian Journal of Administrative Sciences 24:15-29

Ruzzier M, Hisrich RD, Antoncic B (2006) SME internationalization research: past, present, and future Journal of Small Business and Enterprise Development 13:476-497 doi:10.1108/14626000610705705

Santos V, García T (2011) Business motivation and informational needs in internationalization Journal of International Entrepreneurship 9:195-212 doi:10.1007/s 10843-011-0077-y

Shane S (2000) Prior Knowledge and the Discovery of Entrepreneurial Opportunities Organization Science 11:448-469

Shane S, Locke EA, Collins CJ (2003) Entrepreneurial motivation Human Resource Management Review 13:257-279 doi:10.1016/S1053-4822(03)00017-2

Shane S, Venkataraman S (2000) The promise of entrepreneurship as a field of research Academy of management review 25:217-226

Sleuwaegen L, Onkelinx J (2014) International commitment, post-entry growth and survival of international new ventures Journal of Business Venturing 29:106-120 doi:10.1016/j.jbusvent.2013.01.001

Sullivan D (1994) Measuring the Degree of Internationalization of a Firm Journal of International Business Studies 25:325-342 doi:10.2307/155392

Takeuchi R, Tesluk PE, Yun S, Lepak DP (2005) An Integrative View of International Experience The Academy of Management Journal 48:85-100 doi:10.2307/20159642

Verheul I, Van Mil L (2011) What determines the growth ambition of Dutch early-stage entrepreneurs? International Journal of Entrepreneurial Venturing 3:183-207 doi:10.1504/ijev.2011.03934

Westhead P, Wright M, Ucbasaran D (2001) The internationalization of new and small firms: A resource-based view Journal of Business Venturing 16:333-358 doi:10.1016/S08839026(99)00063-4

Wiklund J, Shepherd D (2003) Aspiring for, and achieving growth: The moderating role of resources and opportunities Journal of management studies 40:1919-1941

Zahra SA, Korri JS, Yu J (2005) Cognition and international entrepreneurship: Implications for research on international opportunity recognition and exploitation International Business Review 14:129-146 doi:10.1016/j.ibusrev.2004.04.005

Zhang M, Tansuhaj P, McCullough J (2009) International entrepreneurial capability: The measurement and a comparison between born global firms and traditional exporters in China Journal of International Entrepreneurship 7:292-322 


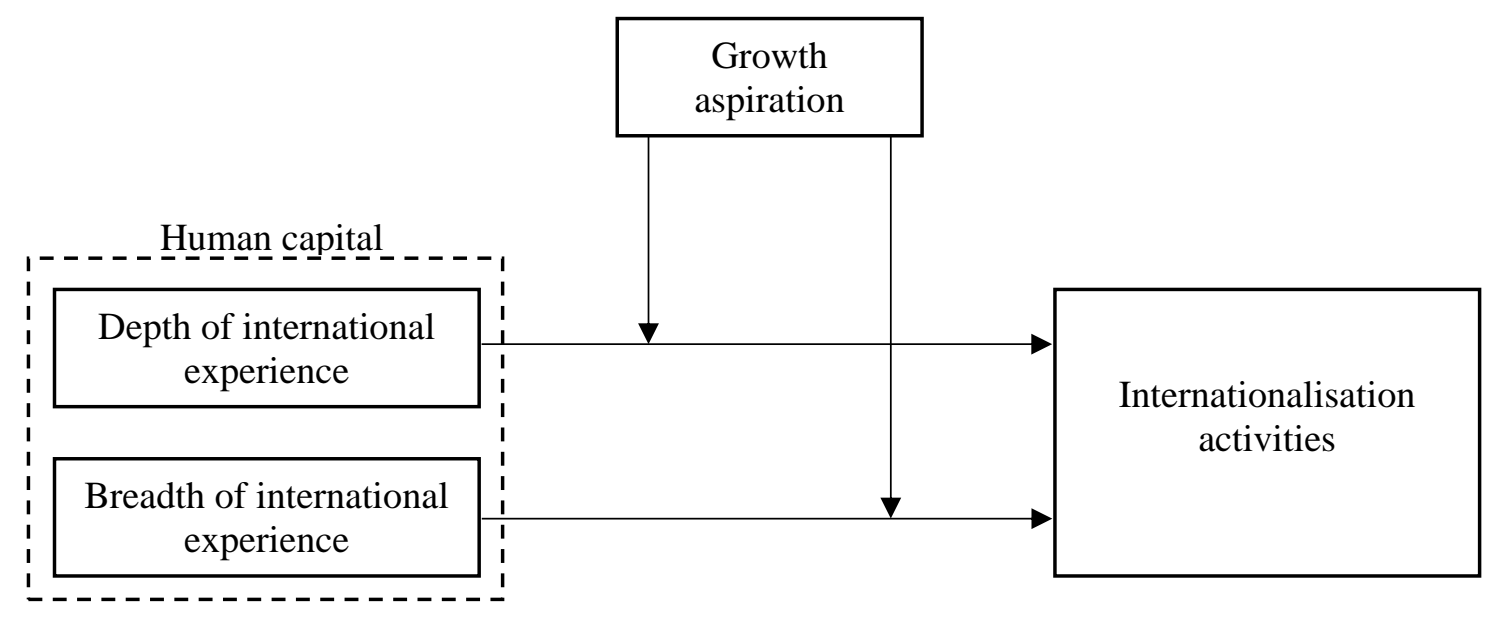

Fig. 1 Research model with proposed relationships

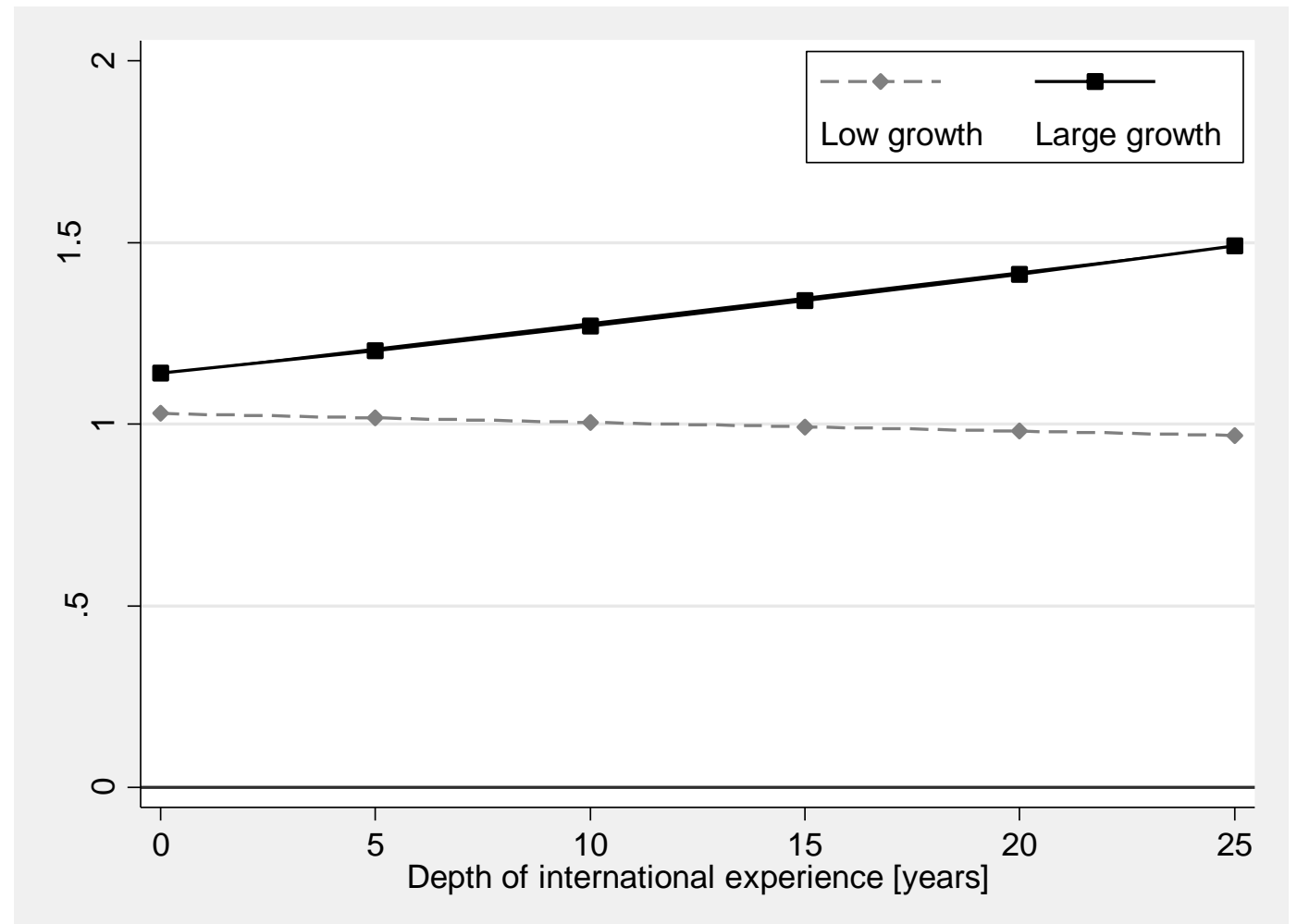

Fig. 2 Interaction of depth of international experience and growth aspiration on internationalisation activities at the time of wave 2 . 
Table 1 Descriptive statistics and correlations

\begin{tabular}{|c|c|c|c|c|c|c|c|c|c|c|c|c|c|c|}
\hline & & Mean & S.D. & 1 & 2 & 3 & 4 & 5 & 6 & 7 & 8 & 9 & 10 & 11 \\
\hline 1 & Young firm & .55 & .50 & & & & & & & & & & & \\
\hline 2 & Brick \& Mortar venture & .68 & .47 & $.31 * * *$ & & & & & & & & & & \\
\hline 3 & Ethnicity of venture team & .22 & .42 & -.01 & -.06 & & & & & & & & & \\
\hline 4 & Gender composition & .37 & .48 & -.00 & .03 & -.02 & & & & & & & & \\
\hline 5 & Service & .63 & .48 & $.18 * * *$ & $.16^{* * *}$ & $-.09 *$ & .06 & & & & & & & \\
\hline 6 & Education & .35 & .48 & .03 & -.05 & .07 & -.06 & -.02 & & & & & & \\
\hline 7 & Depth of international experience & 5.25 & 12.03 & -.07 & $-.08 *$ & $.18^{* * *}$ & .04 & $-.10 * *$ & $.19 * * *$ & & & & & \\
\hline 8 & Breadth of international experience & 1.23 & 3.97 & -.06 & $-.14 * * *$ & $.13 * * *$ & .06 & $-.15 * * *$ & $.09^{*}$ & $.48 * * *$ & & & & \\
\hline 9 & Growth aspiration & .20 & .40 & $-.14 * * *$ & $-.18 * * *$ & .01 & $.09^{*}$ & $-.12 * * *$ & .04 & $.10^{*}$ & $.08^{*}$ & & & \\
\hline 10 & Level of internationalisation W2 & 1.14 & 1.31 & -.05 & $-.24 * * *$ & $.10^{* *}$ & .02 & $-.19 * * *$ & .06 & $.18 * * *$ & $.28 * * *$ & $.13 * * *$ & & \\
\hline 11 & Level of internationalisation W3 & 1.11 & 1.24 & -.05 & $-.28 * * *$ & $.12 * *$ & .01 & $-.15 * * *$ & .08 & $.20 * * *$ & $.28 * * *$ & $.09 *$ & $.61 * * *$ & \\
\hline
\end{tabular}


Table 2 Results from the negative binominal regression analysis on level of internationalisation Waves 2, 3, and 4

\begin{tabular}{|c|c|c|c|c|c|c|c|c|c|}
\hline & \multicolumn{3}{|c|}{ Level of internationalisation Wave 2} & \multicolumn{3}{|c|}{ Level of internationalisation Wave 3} & \multicolumn{3}{|c|}{ Level of internationalisation Wave 4} \\
\hline & $\begin{array}{l}\text { Base } \\
\text { model }\end{array}$ & $\begin{array}{l}\text { Independent } \\
\text { effects }\end{array}$ & $\begin{array}{l}\text { Interaction } \\
\text { effects }\end{array}$ & $\begin{array}{l}\text { Base } \\
\text { model }\end{array}$ & $\begin{array}{l}\text { Independent } \\
\text { effects }\end{array}$ & $\begin{array}{l}\text { Interaction } \\
\text { effects }\end{array}$ & $\begin{array}{l}\text { Base } \\
\text { model }\end{array}$ & $\begin{array}{l}\text { Independent } \\
\text { effects }\end{array}$ & $\begin{array}{l}\text { Interaction } \\
\text { effects }\end{array}$ \\
\hline (Constant) & $.40 * * *$ & $.33 * *$ & $.36 * * *$ & $.36 * *$ & $.29 *$ & $.31 *$ & $.49 * * *$ & $.43 * *$ & $.45^{* *}$ \\
\hline Young firm & .14 & .14 & .15 & .07 & .07 & .10 & -.02 & .02 & .02 \\
\hline Brick \& Mortar venture & $-.49 * * *$ & $-.46^{* * *}$ & $-.47 * * *$ & $-.57 * * *$ & $-.53 * * *$ & $-.55 * * *$ & $-.34 * *$ & $-.34 * *$ & $-.34 * *$ \\
\hline Ethnicity of venture team & .18 & .11 & .12 & $.30 * *$ & $.24 *$ & $.25^{*}$ & .24 & .21 & .23 \\
\hline Gender composition & .08 & .04 & .04 & .14 & .10 & .10 & .15 & .13 & .13 \\
\hline Service & $-.36 * * *$ & $-.31 * * *$ & $-.31 * * *$ & $-.21 *$ & -.15 & -.16 & $-.55 * * *$ & $-.52 * * *$ & $-.53 * * *$ \\
\hline Education & .11 & .07 & .08 & .13 & .09 & .10 & $.27 *$ & $.24 *$ & $.25^{*}$ \\
\hline Growth aspiration & $.22 *$ & .20 & .11 & .08 & .07 & -.03 & .05 & .02 & .02 \\
\hline Depth of international experience & & .00 & -.00 & & .00 & -.00 & & .00 & -.00 \\
\hline Breadth of international experience & & $.02 * *$ & $.03 * *$ & & $.02 *$ & $.03 *$ & & .02 & .02 \\
\hline Depth of int. exp. $*$ growth aspiration & & & $.01 *$ & & & $.01 *$ & & & .01 \\
\hline Breadth of int. exp. $*$ growth aspiration & & & -.01 & & & -.01 & & & -.04 \\
\hline$n$ & 689 & 689 & 689 & 499 & 499 & 499 & 378 & 378 & 378 \\
\hline Model $\chi^{2}$ & $80.5 * * *$ & $85.0 * * *$ & $111.4 * * *$ & $58.0 * * *$ & $74.6^{* * *}$ & $83.2 * * *$ & $55.8 * * *$ & $51.1 * * *$ & $54.1 * * *$ \\
\hline Log likelihood & -974.9 & -967.0 & -965.0 & -693.8 & -688.8 & -686.7 & -530.2 & -528.9 & -528.2 \\
\hline Cox \& Snell R ${ }^{2}$ & .09 & .11 & .12 & .10 & .12 & .13 & .12 & .12 & .13 \\
\hline Nagelkerke $\mathrm{R}^{2}$ & .10 & .12 & .12 & .11 & .12 & .13 & .12 & .13 & .13 \\
\hline Likelihood ratio $\chi^{2}$ & 65.0 & 15.9 & 3.8 & 52.2 & 10.1 & 4.1 & 47.3 & 2.7 & 1.4 \\
\hline Model delta sig. & .000 & .000 & .146 & .000 & .007 & .127 & .000 & .257 & .507 \\
\hline
\end{tabular}

$* \mathrm{p}<.05 ; * * \mathrm{p}<.01 ; * * * \mathrm{p}<.001$. One-tailed significance levels are reported for hypothesised relationships. Two-tailed significance is reported for non-hypothesised relationships. 
Table 3 Results from the logistic regression analysis on International Sales Waves 2, 3, and 4

\begin{tabular}{|c|c|c|c|c|c|c|c|c|c|}
\hline & \multicolumn{3}{|c|}{ International Sales Wave 2} & \multicolumn{3}{|c|}{ International Sales Wave 3} & \multicolumn{3}{|c|}{ International Sales Wave 4} \\
\hline & $\begin{array}{l}\text { Base } \\
\text { model }\end{array}$ & $\begin{array}{l}\text { Independent } \\
\text { effects }\end{array}$ & $\begin{array}{l}\text { Interaction } \\
\text { effects }\end{array}$ & $\begin{array}{l}\text { Base } \\
\text { model }\end{array}$ & $\begin{array}{l}\text { Independent } \\
\text { effects }\end{array}$ & $\begin{array}{l}\text { Interaction } \\
\text { effects }\end{array}$ & $\begin{array}{l}\text { Base } \\
\text { model }\end{array}$ & $\begin{array}{l}\text { Independent } \\
\text { effects }\end{array}$ & $\begin{array}{l}\text { Interaction } \\
\text { effects }\end{array}$ \\
\hline (Constant) & $-1.03 * * *$ & $-1.20 * * *$ & $-1.12 * * *$ & $-.95 * *$ & $-1.21 * * *$ & $-1.16^{* *}$ & -.44 & -.65 & -.65 \\
\hline Young firm & $.78 * *$ & $.86^{* *}$ & $.89 * * *$ & $.79 * *$ & $.91 * *$ & $.95 * *$ & .41 & .55 & .55 \\
\hline Brick \& Mortar venture & $-1.14 * * *$ & $-1.12 * * *$ & $-1.15 * * *$ & $-1.56 * * *$ & $-1.53 * * *$ & $-1.56 * * *$ & $-1.10 * *$ & $-1.08 * *$ & $-1.07 * *$ \\
\hline Ethnicity of venture team & .29 & .14 & .19 & $.64^{*}$ & .49 & .53 & $.71 *$ & .64 & $.78^{*}$ \\
\hline Gender composition & -.05 & -.13 & -.13 & .23 & .16 & .15 & -.16 & -.21 & -.26 \\
\hline Service & $-.80 * * *$ & $-.73 * * *$ & $-.76 * * *$ & $-.83 * *$ & $-.72 * *$ & $-.76 * *$ & $-1.45 * * *$ & $-1.39 * * *$ & $-1.48 * * *$ \\
\hline Education & .31 & .23 & .25 & .32 & .21 & .22 & $.72 *$ & $.64^{*}$ & $.65^{*}$ \\
\hline Growth aspiration & .47 & .43 & .21 & .21 & .19 & .07 & -.47 & -.57 & -.42 \\
\hline Depth of international experience & & .00 & -.02 & & .00 & -.02 & & .00 & -.03 \\
\hline Breadth of international experience & & $.11 * *$ & $.16^{*}$ & & $.13 * *$ & $.18 * *$ & & $.12 *$ & $.29 *$ \\
\hline Depth of int. exp. ${ }^{*}$ growth aspiration & & & $.05^{*}$ & & & .04 & & & .06 \\
\hline Breadth of int. exp. $*$ growth aspiration & & & -.09 & & & -.11 & & & -.44 \\
\hline$n$ & 689 & 689 & 689 & 499 & 499 & 499 & 378 & 378 & 378 \\
\hline Model $\chi^{2}$ & $46.7 * * *$ & $54.1 * * *$ & $53.5 * * *$ & $51.1 * * *$ & $51.8 * * *$ & $48.4 * * *$ & $41.6^{* * *}$ & $42.5 * * *$ & $37.0 * * *$ \\
\hline Log likelihood & -304.8 & -297.4 & -294.0 & -209.3 & -202.6 & -201.1 & -162.3 & -159.6 & -154.9 \\
\hline Cox \& Snell R ${ }^{2}$ & .08 & .10 & .11 & .12 & .14 & .14 & .13 & .14 & .16 \\
\hline Nagelkerke $\mathrm{R}^{2}$ & .14 & .17 & .18 & .19 & .23 & .23 & .20 & .22 & .26 \\
\hline Likelihood ratio $\chi^{2}$ & 60.7 & 14.7 & 7.0 & 61.3 & 13.5 & 3.0 & 51.9 & 5.5 & 9.4 \\
\hline Model delta sig. & .000 & .001 & .030 & .000 & .001 & .221 & .000 & .063 & .009 \\
\hline
\end{tabular}

$* \mathrm{p}<.05 ; * * \mathrm{p}<.01 ; * * * \mathrm{p}<.001$. One-tailed significance levels are reported for hypothesised relationships. Two-tailed significance is reported for non-hypothesised relationships. 